\title{
STUDI DAMPAK COVID 19 TERHADAP PEREKONOMIAN PROVINSI PAPUA 2020
}

\author{
Mesak Iek ${ }^{1}$ \\ imesakick@yahoo.com \\ 1 Dosen Jurusan IImu Ekonomi Fakultas Ekonomi dan Bisnis Universitas Cenderawasih
}

\begin{abstract}
Abstraksi:
Kajian ini bertujuan untuk mendeskripsikan dampak COVID-19 terhadap kinerja ekonomi kesempatan kerja dan harga pada 9 bahan pokok serta terhadap pemanfatan tekhnolog dalam proses Belajar mengajar. Lokasi kajian di Provinsi Papua dengan wilayah sampel kota Jayapura, dengan alasan, kota Jayapura merupakan pusat aktivitas social dan ekonomi di provinsi Papua, dan penduduknya sangat padat secara rill. Data yang digunakan data primer dan dekunder. Teknik pengumpulan data melalui studi pustaka dan survey lapang. Dari kajian ini ditemukan bahwa Dampak Covid 19 terhadap pertumbuhan ekonomi Provinsi Papua pada triwulan I tahun 2020, mencapai 1,48 persen (yoy), pada triwulan II-2020, mencapai pertumbuhan sebesar 4,52 persen, namun pada triwukan III tahun 2020 terjadi kontraksi sebesar 2,62 persen, lebih kecil dibandingkan dengan pertumbuhan secara nasional terjadi kontraksi sebesar 3,49 persen. Tingkat Pengangguran Terbuka (TPT) pada Februari 2020 sebesar 66.296 orang atau meningkat 7,13 persen dibanding Februari 2019 hanya 61.885 orang (meningkat 4.411 orang). Dampak Covid 19 terhadap pemutusan hubungan kerja di Papua sebanyak 2.602 orang yang dirumahkan, dan ini tersebar di beberapa kota besar seperti Kota Jayapura sebanyak 1.452 orang, Kabupaten Jayapura sebanyak 465 orang, Keerom sebanyak 79 orang dan Kabupaten Merauke sebanyak 66 orang. Hasil Survey menunjukkan sebanyak 53.10 persen responden menyatakan bahwa harga 9 bahan kebutuhan pokok mengalami peningkatan di masa pandei covi'19. Dari responden pelajar dan mahasiswa yang disurvey 95 persen responden menyatakan mereka menggunakan fasilitas internet untuk belajar/mengajar di era pandemic Covid 19 ini. Sisanya sebesar 5 persen menyatakan "tidak pernah". Aplikasi yang sering digunakan dalam proses pembelajaran 61,3 persen menggunakan WhatsApp dan 55,4 persen menggunakan aplikasi zoom, sisanya menggunakan lainnya. Dari survey ditemukan bahwa 23,4 persen responden adalah guru/dosen yang tidak pernah menggunakan vasilitas internet sebagai media pembelajaran. Kendala yang dihadapi guru/dosen : tidak tahu atau lainnya dan tidak memiliki akses internet.
\end{abstract}

Kata Kunci : Dampak Ekonomi, COVID-19, dan Kinerja Ekonomi, Provinsi Papua.

\section{PENDAHULUAN}

\section{A. Latar Belakang}

Gejolak ekonomi yang terjadi sebagai akibat penyebaran virus corona tahun 2019 atau sering disebut pandemi covid 19 terhadap perekonomian masyarakat, baik di dunia global, nasional maupun regional sudah masuk pada fase krisis. Gejolak ekonomi yang terjadi ini juga menghatam perekonomian Indonesia secara keseluruhan tidak terkecuali perekonomian Provinsi Papua. Kendisi pandemic ini sangat mempengaruhi perilaku sosial ekonomi masyarakat di seluruh dunia, Indonesia dan secara khusus Papua. Gejolak ekonomi kali ini sangat berbeda dengan gejolak ekonomi yang terjadi sebelumnya. Khusus di Indonesia, bahwa gejolak ekonomi yang pernah terjadi, misalnya di tahun 1998 dan 2008, ternyata pandemic kali ini (2020) memliki karakteritik yang aga berbeda dengan gejolak yang terjadi sebelumnya. Misalnya saja pada tahun 1998, ketika demo besar-besar yang menjatuhkan resim Orde Baru terjadi gejolak krisis keuangan akibat adanya kombinasi masalah dari ekonomi dan politik yang terjadi di Indonesia. Sementara krisis tahun 2008 adalah ketika itu harga komoidtas dunia jatuh. Sedangkan pada krisis 2008 sendiri tidak semua negara merasakan dampaknya. Sementara dampak krisis ekonomi yang terjadi pada 2008 di Indonesia lebih menyerang ke sektor keuangan dan korporasi. Fondasi Ekonomi Indonesia pada krisis sebelumnya (1998 dan 2008) masih kuat dibanding kondisi saat Covid 19 ini, di mana sector UKMK, UKM sert sector non-formal lainnya tetap bergerak dan menghidupkan ekonomi masyarakat. Kondisi ini sangat berbeda jauh dengan Pandemik COVID-19 tahun 2020 ini.

Pendemik covid 19 telah sangat nyata mengubah perilaku ekonomi masyarakat Indonesia dengan produktivitas yang semakin memburuk. Pertanyaan bagi kita adalah Indonesia akan mampu melawan gejolak ekonomi yang akan terjadi sebagai akibat Pandemi Covid 19 ini. Para Ekonom banyak memprediksi bahwa Indonesia akan mengalami pertumbuhan 
ekonomi yang negative di atas 5 persen. Kepala Kantor Perwakilan Bank Indonesia Provinsi Papua melaporkan bahwa dampak ekonomi Papua pada masa covid-19 di perbatasan RI-PNG Skouw tidak ada transaksi perdagangan dari bulan Januari dengan opportunity lost Rp. 4 M/bln, sektor lain transportasi opportunity lost Rp. 385 miliar/bulan, Makan minum menurun $50 \%$, akomodasi occupancy rate 70 dan pertambangan belum ada eskpor. Dengan semakin berkembangnya penyebaran COVID-19, Bank Indonesia beberapa kali harus menurunkan proyeksi pertumbuhan ekonomi Papua dari awalnya diperkirakan tumbuh 7,29\% turun menjadi 2,24\%, harga komoditas yang dijual di Papua termasuk yang tertinggi di Indonesia sehingga perlu ada solusi jangka panjang, dalam upaya pengendalian inflasi ada TPID dan BI yang membuatkan strategi untuk jangka pendek dan jangka Panjang. Selanjutnya dilaporkan bahwa terjadi penurunan omset penjualan harian, stok bahan pangan dapat memenuhi kebutuhan hingga 3 bulan kedepan. Data dari Bulog memberikan gambaran bahwa stok komoditas beras cukup untuk memenuhi kebutuhan hanya 3 sampai 4 bulan dan stok gula pasir yang menipis akan mulai didistribusikan ke Papua pada akhir bulan April 2020 dan akan berdampak lanjut pada bulan-bulan berikutnya.

Kondisi ini terjadi jika pemerintah pusat maupun daerah lebih menguatamakan penerapan kebijakan penanganan COVID-19 dan kurang memperhatikan kebijakan pemulihan ekonominya. Oleh karena itu diperlukan kajian yang cepat dan mandala serta fokus pada rumusan kebijakan yang tepat, yang didasari pad riset yang akurat dan menyeluruh sehingga melahirkan kebijakan penanganan pandemik dan pemulihan ekonomi yang terukur dan komprehensif sehingga akan terhindak dari krisis ekonomi yang semakin parah.

Para ekonom Indonesia dituntut untuk mengambil peran dalam perumusan kebijakan ekonomi yang mengarah pada pemulihan ekonomi Indonesia. Inisiatif para ekonom yang tersebar di seluruh daerah, termasuk di Provinsi Papua sangat dinantikan guna melahirkan kebijakan penanganan dan pemulihan ekonomi, guna mencegah terjadinya krisis ekonomi yang semakin parah. Dalam kondisi inilah kajian Dampak Covid 19 terhadap Perekonomian Daerah Provinsi Papua ini dilakukan.

\section{B. Rumusan Masalah}

Sehubungan dengan uraian latar belakang sebelumnya, maka penulis merumuskan beberapa permasalahan yang ingin dikaji lebih mendalam antara lain :

a. Bagaimana Dampak Covid 19 terhadap perekonomian Provinsi Papua tahun 2020 ?

b. Bagaimana dampak Covid 19 terhadap kesempatan kerja di Provinsi Papua tahun 2020 ?

c. Bagaimana dampak Covid 19 terhadap harga 9 bahan kebutuhan pokok di provinsi Papua ?

d. Bagaimana dampak Covid 19 terhadap proses pendidikan di Papua?

\section{Tujuan Penelitian}

Berdasarkan rumusan masalah yang dikemukakan di atas, maka tujuan penelitian ini adalah sebagai berikut:

1. Memberi masukan kepada pemerintah dan pemerintah daerah Provinsi Papua terkait dampak COVID-19 terhadap kinerja ekonomi dan sosial Provinsi Papua;

2. Sebagai sharing informasi dan metodologi kajian terapan dampak COVID-19 pada kinerja ekonomi dan sosial Papua; dan

3. Memberi kontribusi pemikiran dan kepedulian peneliti bidang ekonomi kepada masalah ekonomi dan sosial di Provinsi Papua.

\section{LANDASAN TEORI}

\section{A. Kajian Teori}

\section{Sejarah Covid-19}

Virus Corona sudah dikenal sejak tahun 1930-an dan diketahui terdapat pada hewan. Pada Tahun 2002, muncul penyakit baru golongan Virus Corona yang menyebabkan penyakit Severe Acute Respiratory Syndrome ((SARS). Pada tahun 2012, muncul lagi golongan Virus Corona ini yang menyebabkan penyakit Middle East Respiratory (MERS) di Timur Tengah, khususnya Negara-negara Arab. 
Kasus Covid'19 pada bulan Desember 2019, di kota Wuhan, Tiongkok terjadi kejadian luar biasa (KLB), kasus radang paru-paru (pneumonia) yang disebakan oleh virus dari keluarga besar Virus Corona, tetapi virus ini belum pernah dikenal sebelumnya, sehingga disebut sebagai corona jenis baru atau Novel Coronavirus (= novel, palin baru), Sutaryo, dkk (2020).

Wabah Covid'19 merambat masuk ke Indonesia melalui WNA Jepang yang melakukan kontak pertama dengan dua orang Indonesia yang merupakan pasien pertama, salah satunya merupakan guru dansa. Pasien ini melakukan kontak fisik dengan WNA Jepang. WNA Jepang ini bermukim di Malaysia sejak 14 Februari 2020, selanjutnya ke Indonesia. Selang dua hari, yakni 16 Februari 2020 pasien terkena sakit batuk dan diperiksa ternyata positif selanjutnya pasien dipindahkan ke Rumah Sakit Penyakit Infeksi (RSPI) Sulianti Saroso, Jakarta Utara. Wabah ini bergerak cepat dan sampai di wilayah Provinsi Papua sejak pertengahan Maret 2020, pada saat awal tanggal 26 Maret 2020, Pasien Positif Covid-19, hanya 7 Pasien, namun setelah sampai 4 Mei sudah mencapai 240 orang positif covid'19, pasien yang dirawat sebanyak 173 pasien dan sembuh 60 orang serta pasien meninggal dunia sebanyak 7 orang, dan terus meningkat sampai 7 Agustus 2020, jumlah orang positif Covid'19 sudah mencapai 3.120 orang, yang dirawat di rumah sakit sebanyak 1.163 orang atau 41 persen, dari total di rawat tersebut sebanyak 58 persen (1.822 orang ) sembuh dan hanya 1,9 persen (35 pasien) yang meninggal dunia. Semua pasien covid ini di rawat pada 47 Rumah Sakit di Provinsi Papua.

\section{Dampak Pandemic Covid 19 Terhadap Aktivitas Sosial dan Ekonomi Masyarakat}

Ada beberapa tulisan yang telah mencoba menguraikan kasus pandemic Covid 19 di beberapa Negara-negara besar di dunia, seperi dalam buku "Praktis Penyakit Virus Corona 19" kakarangan Sutaryo, dkk (2020), menyatakan bahwa: salah satu negara yang cukup berhasil bersiaga perang melawan covid 19 yakni : Singapura, yang merupakan kota pusat perdagangan dan pariwisata dunia dapat bertahan dengan baik dan terstruktur, karena masyarakat yang terbiasa hidup bersih dan taat aturan. Hal ini dinyatakan oleh Menkes RI (Germas, 2020) bahwa kemungkinan factor penyebab penularan COVID-19 dan potensi wilayah adalah (1) Faktor Perilaku masayarakat yang hidup tidak disiplin dan tidak melakukan, PHBS/CTPS, dan (2) Non Perilaku: lingkungan, masalah lingkungan yang kurang sehat serta (3) Mendata potensi sumber daya manusia dan sumber daya dana dan sarana pendukung. Selain Singapura, Korea Selatan juga merupakan negara yang bergerak cepat dalam menangani pandemic Covid 19 ini secara baik. Namun ada beberapa Negara menghadapi masalah sama seperti Indonesa, misalnya Inggris Raya, terpaksa menutup sekolah-sekolah, pertandingan bola kaki kelas dunia dihentikan, di India, banyak Pabrik di tutup para buruh dipulangkan ke kampung halannya masing-masing. Negara Sakura Jepang juga menutup sekolah-sekolah dan jalan Tol serta melakukan karantina terhadap orang-orang yang datang dari Negara Cina. Kondisi ini terjadi di seluruh dunia dan sangat berdampak pada masalah ekonomi dunia maupum ekonomi regional masing-masing negara.

Penelitian yang dilakukan oleh Dito,dkk (2020) dengan judul : Dampak Pandemi Covid 19 Terhadap Perekonomian Indonesia, dengan menggunakan metode kuantitatif deskriptif dengan menggunakan pendekatan analisis data sekunder, ditemukan bahwa : terdapat 93 negara yang telah terjangkit COVID-19 dan telah menyebar membawa risiko yang sangat buruk bagi perekonomian dunia termasuk Indonesia dan sector yang mendapat dampak cukup parah antara lain : sektor pariwisata, perdagangan serta investasi. Di mana pandemi COVID-19 menyebabkan rendahnya sentimen investor terhadap pasar yang pada akhirnya membawa pasar ke arah cenderung negative, lambatnya ekonomi global khususnya kegiatan ekspor Indonesia ke China juga berdampak signifikan terhadap perekonomian Indonesia. Kajian yang dilakunan oleh Silpa Hanoatubun (April 2020), menyimpulkan bahwa dampak Covid-19 terhadap perekonomian Indonesia saat ini dengan berbagai dampak yaitu terjadi kesulitan dalam mencari lapangan pekerjaan, kesulitan untuk memenuhi kebutuhan hidup sehari-hari dan juga tidak mempunyai penghasilan tetap dalam memenuhi kebutuhan sehari-hari. Penelitian yang dilakukan oleh Agus Purwanto, dkk (2020), dengan judul : Studi Eksploratif Dampak Pandemi Covid19 Terhadap Proses Pembelajaran Online di Sekolah Dasar, dan menggunakan metode studi kasus eksplorasi dan pendekatan penelitiannya menggunakan metode studi kasus kualitatif yang digunakan untuk mendapatkan informasi kendala dan akibat dari pandemic Covid-19 terhadap kegiatan proses belajar mengajar di sekolah dasar, dengan responden sebanyak 6 orang guru dan orang tua murid di sebuah sekolah dasar di Tangerang. Untuk tujuan kerahasiaan maka, responden diberi inisial R1, R2, R3, R4, R5 dan R6. Wawancara semi-terstruktur dilakukan dan daftar pertanyaan disusun untuk wawancara dikembangkan 
berdasarkan literatur terkait. Hasil penelitian ini menemukan bahwa ada beberapa kendala yang dialami oleh murid, guru dan orang tua dalam kegiatan belajar mengajar online yaitu kurangnya penguasaan teknologi, penambahan biaya kuota internet, adanya pekerjan tambahan bagi orang tua dalam mendampingi anak belajar, komunikasi dan sosialisasi antar siswa, guru dan orang tua menjadi berkurang dan Jam kerja yang menjadi tidak terbatas bagi guru karena harus berkomunikasi dan berkoordinasi dengan orang tua, guru lain, dan kepala sekolah.

Dampak Covid 19 ini melanda seluruh aspek kehidupan masyarakat di dunia, termasuk Indonesia dan lebih khusus Papua yang selama ini kebutuhan hidup sangat tergantung pada barang-barang impor dari luar Papua. Keadaan ekonomi masyarakat sangat terganggu dan menyebabkan hampir semua masyarakat turun ke ladang untuk mengolah lahan yang selam ini menjadi lahan tidur. Seperti ada kesadaran baru bagi orang asli papua yang selama ini di manja dengan mengkonsumsi beras yang diimpor dari luar.

\section{METODE PENELITIAN}

\section{A. Lokasi Penelitian}

Kajian ini dilakukan di Provinsi Papua dan focus kajian di kota Jayapura, dengan alasan bahwa Kota Jayapura merupakan pusat semua aktivitas social ekonomi dan politik di provinsi Papua, dan penduduknya cukup padat secara rill.

\section{B. Jenis dan Sumber Data}

Kajian ini mempergunakan dua jenis data berdasarkan sumbernya, yakni data Primer dan Sekunder. Data primer ditujukan untuk analisis subyektif, berupa persepsi ekonom daerah Provinsi Papua pada kondisi ekonomi daerah. Data sekunder ditujukan untuk analisis obyektif berupa kondisi obyektif kinerja perekonomian daerah Provinsi Papua meliputi pertumbuhan ekonomi, tingkat inflasi, tingkat pengangguran, kondisi fiskal daerah, serta data sekunder terkait perbankan nasional dan regional.

\section{Metode Analisis}

Analisis data dilakukan dengan pendekatan metode deskriptif. Menyajikan dan memaparkan fakta obyektif data sekunder dan fakta subyektif data primer, berupa persepsi ekonom terhadap penerapan kebijakan penanganan dan pemulihan ekonomi pada masa pandemik. Analisis deskripsi ini juga akan didukung analisis konten terhadap kebijakankebijakan yang telah dan akan diterapkan oleh pemerintah dan pemerintah daerah Provinsi Sulsel. Memaparkan pemetaan sederhana melalui analisis klaster daerah terhadap kondisi kasus pandemik dan kinerja ekonomi daerah, serta kondisi kinerja ekonomi dan rumusan/terapan kebijakan daerah Provinsi Papua.

\section{HASIL DAN PEMBAHASAN}

\section{A. Indikator Ekonomi dan Sosial Provinsi Papua}

Keuangan Pemerintah Realisasi APBN lingkup Provinsi Papua pada triwulan III 2020 mengalami penurunan baik pada pos pendapatan maupun pos belanja dibandingkan dengan periode yang sama pada tahun 2019. Pendapatan APBN lingkup Provinsi Papua tumbuh menurun sebesar 0,66\% (yoy) dan Belanja APBN lingkup Provinsi Papua terkontraksi sebesar 16,08\% (yоy). Sumber pendapatan terbesar berasal dari Pajak Dalam Negeri sedangkan realisasi belanja terbesar berasal dari Belanja Barang dan Belanja Modal. Selain itu, realisasi APBD lingkup Provinsi Papua pada triwulan III 2020 mengalami peningkatan di sisi pendapatan, sedangkan sisi belanja mengalami penurunan dibandingkan dengan triwulan III 2019. Pos pendapatan meningkat sebesar 34,18\% (yoy) dipengaruhi terutama oleh percepatan transfer dari Pemerintah Pusat untuk pemulihan ekonomi akibat pandemi COVID-19. Sedangkan pos belanja mengalami penurunan sebesar 3,33\% (yoy).

Perkembangan Inflasi Daerah, tekanan inflasi Papua pada triwulan III 2020 sebesar 1.93 \% (yoy) meningkat jika dibandingkan dengan triwulan II 2020 sebesar 1,03\% (yoy), namun menurun jika dibandingkan dengan triwulan III 2019 sebesar 2,69\% (yoy). Dilihat dari kelompok komoditasnya, penyumbang inflasi tertinggi adalah kelompok komoditas 
makanan, minuman, dan tembakau; perawatan pribadi dan jasa lainnya; dan transportasi dengan andil masing-masing sebesar 1,04\% (yoy); 0,41\% (yoy); dan 0,20\% (yoy). Secara spasial, Kab. Merauke mengalami penurunan inflasi sedangkan Kota Jayapura dan Kab. Mimika mengalami peningkatan dibandingkan dengan triwulan sebelumnya.

Tim Pemantau Inflasi daerah (TPID) Kota Jayapura memperoleh TPID Kab/Kota Terbaik untuk kategori wilayah Nusa Tenggara - Maluku-Papua. Hal tersebut merupakan wujud penghargaan dan apresiasi pemerintah pusat terhadap koordinasi penanganan inflasi di Papua (Laporan BI Papua Triulan III, 2020).

Stabilitas Keuangan Daerah, Stabilitas Keuangan Daerah di Papua ditopang oleh kinerja keuangan sektor korporasi dan rumah tangga pada triwulan III 2020 secara umum masih terjaga dengan baik pada tingkat yang aman namun dengan peningkatan risiko. Kinerja perbankan pada sektor Korporasi di Papua pada triwulan III 2020 relatif membaik tercermin dari peningkatan penyaluran kredit dan disertai dengan penurunan NPL. Namun demikian, terjadi penurunan penghimpunan dana korporasi serta peningkatan LAR sejalan dengan meningkatnya restrukturisasi kredit di masa pandemi COVID-19. Selanjutnya, kinerja sektor Rumah Tangga pada triwulan III 2020 relatif belum pulih, tercermin dari keyakinan masyarakat terhadap kondisi ekonomi yang menurun. Namun demikian, kondisi keuangan masyarakat mulai membaik sejalan dengan peningkatan penghimpunan dana dan penyaluran kredit disertai dengan penurunan NPL.

Penyelenggaraan Sistem Pembayaran dan Pengelolaan Uang Rupiah Perkembangan transaksi non tunai di Provinsi Papua pada triwulan III 2020 secara umum mengalami peningkatan dibandingkan dengan triwulan II 2020, meskipun belum mencapai level pertumbuhan pada triwulan III 2019. Transaksi SKNBI di Papua pada triwulan III 2020 mengalami peningkatan sebesar 17,99\% (qtq). Kemudian, aliran uang kartal melalui Kantor Perwakilan Bank Indonesia Provinsi Papua menunjukkan posisi net outflow pada triwulan III 2020 sebesar Rp296 miliar tidak sebesar periode yang sama tahun sebelumnya mencapai net outflow Rp1,21 triliun. Hal ini merupakan dampak pandemi COVID-19 yang menurunkan aktivitas ekonomi secara umum.

Dampak pandemi Covid-19 terhadap perekonomian daerah, dimulai pada pembatasan aktivitas masyarakat di luar rumah atau Pembatasan Sosial Berskala Besar (PSBB) dimulai sejak Maret - Juli 2020, sebagai upaya pemerintah menekan laju pertambahan kasus harian penderita covid 19. Kebijakan PSBB yang didasarkan pada Peraturan Pemerintah No. 21 Tahun 2020 Tentang PSBB. Hal ini dalam rangka percepatan penanganan Covid-19 yang secara langsung menghantam perekonomian daerah dari dua sisi, permintaan dan penawaran. Aktivitas produksi nyaris berhenti sementara kegiatan konsumsi rumah tangga juga mengalami penurunan tajam.

Dampak dari kebijakan PSBB terhadap perekonomian daerah mulai kelihatan pada triwulan I tahun 2020, ditunjukkan dengan angka pertumbuhan ekonomi 1,48 persen (yoy), lebih lambat dibandingkan triwulan sebelumnya $(q-t o-q)$, Perekonomian terjadi kontraksi sebesar $-6,77$ persen atau turun sebesar $-6,77$ persen. Namun pada triwulan II-2020, Ekonomi Papua mengalami pertumbuhan sebesar 4,52 persen (dengan Tambang) (y-on-y). Dari 17 kategori lapangan usaha terdapat lima lapangan usaha yang mengalami pertumbuhan positif selama triwulan II 2020. Dari sisi produksi, pertumbuhan tertinggi dialami oleh lapangan usaha Pertambangan dan Penggalian sebesar 29,92 persen. Dari sisi Pengeluaran, pertumbuhan tertinggi terdapat pada Komponen Ekspor Luar Negeri sebesar 60,35 persen. Ekonomi Papua triwulan II-2020 dibandingkan triwulan sebelumnya (q-to-q) mengalami pertumbuhan sebesar 3,45 persen. Meskipun sebagian besar lapangan usaha mengalami penurunan produksi, naiknya angka pertumbuhan ekonomi tersebut disebabkan karena tingginya pertumbuhan lapangan usaha yang memiliki kontribusi terbesar terhadap PDRB Provinsi Papua, yaitu sector Pertambangan dan Penggalian. Sementara dari sisi Pengeluaran, disebabkan oleh pertumbuhan Komponen Ekspor Luar Negeri, Pengeluaran Konsumsi Pemerintah (PKP) dan Pembentukkan Modal Tetap Bruto (PMTB). PDRB per kapita pada Triwulan II-2020 mencapai Rp 13,98 Juta. Sementara PDRB Perkapita Tanpa Pertambangan dan Penggalian sebesar Rp. 10,11 Juta. (BPS Papua, 5 Agustus 2020). 
Gambar. 1. Pertumbuhan Ekonomi Papua dengan Tambang tahun 2018-2020 pertriwulan

\section{Pertumbuhan Ekonomi Papua Pertriwulan 2018-2020}

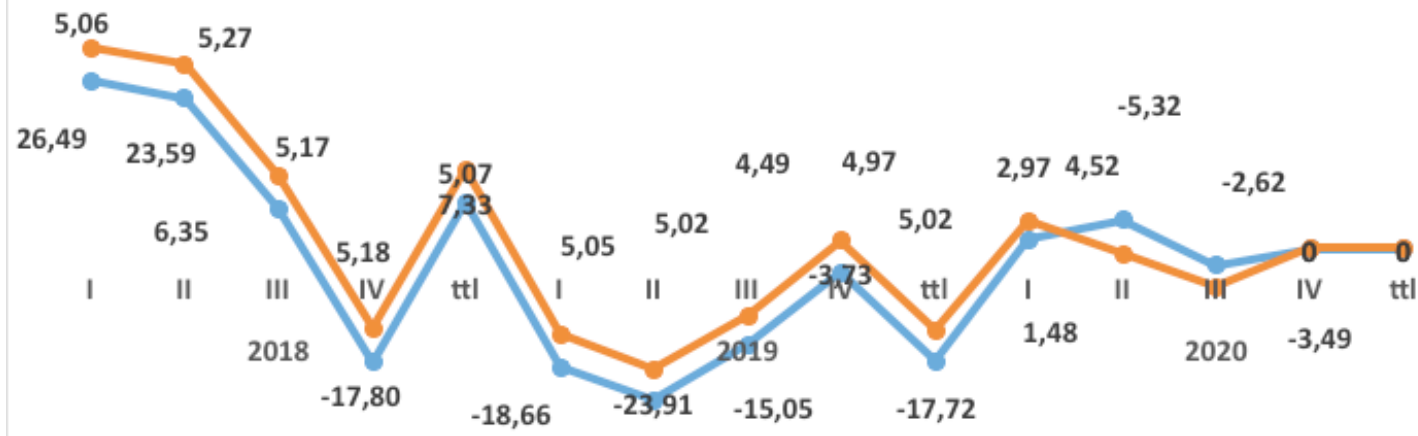

Pertumbuhan Ekonomi Papua (\%, yoy) - Pertumbuhan Ekonomi Nasional (\%, yoy)

Sumber : Data BPS Papua diolah 2021

Ekonomi Papua selama triwulan II-2020 jika dibandingkan dengan triwulan II-2019, mengalami pertumbuhan sebesar 4,52 persen, walaupun sebagian besar lapangan usaha mengalami penurunan produksi akibat adanya pandemi Covid-19. Pertumbuhan tersebut terjadi sebagai akibat adanya peningkatan produksi pada tambang bijih logam PT. Freeport Indonesia selama triwulan II 2020 yang membawa pertambangan dan penggalian tumbuh mencapai 29,92 persen, mengalami peningkatan dibandingkan triwulan II-2019, namun, jika perekonomian Papua tanpa Tambang mengalami kontraksi pertumbuhan cukup besar. Ekonomi Papua Tanpa Pertambangan dan Penggalian triwulan II-2020 dibanding triwulan II-2019 (y-on-y) mengalami kontraksi pertumbuhan sebesar -4,50 persen, mengalami penurunan dibandingkan dengan periode triwulan II-2019 (y on y) yaitu sebesar 5,73 persen. Dari sisi kontribusi, lapangan usaha Konstruksi (F) merupakan kategori yang mendominasi ekonomi Papua tanpa tambang yaitu sebesar 20,70 persen, disusul oleh kategori Pertanian Kehutanan dan Perikanan (A) sebesar 18,12 persen. Kategori Administrasi Pemerintahan, Pertahanan dan Jaminan Sosial Wajib (0) berada pada posisi berikutnya sebesar 15,09 persen, disusul kategori Perdagangan Besar dan Eceran; Reparasi Mobil dan sepeda motor $(G)$ sebesar 14,04, dan disusul kategori yang lain yang kontribusinya masih berada dibawah 10 persen terhadap ekonomi Papua. Kategori yang mengalami kontraksi serius selama triwulan II 2020 adalah Transportasi dan Pergudangan sebesar $-49,90$ persen; Penyediaan akomodasi, makan dan minum sebesar -24,43 persen; dan jasa perusahaan sebesar $-13,53$ persen. Namun pertumbuhan ekonomi Papua pada triwukan III tahun 2020 terjadi kontraksi sebesar 2,62 persen, lebih kecil dibandingkan dengan pertumbuhan secara nasional terjadi kontraksi sebesar 3,49 persen, walaupun pada triwulan II ekonomi nasional terjadi kontrasi sebesar 5,32 persen.

\section{B. Dampak Covid 19 Terhadap Kesempatan Kerja}

Ketenagakerjaan dan Kesejahteraan, Pada periode Agustus 2020 jumlah penduduk yang bekerja di Papua sebesar 1,69 juta orang, mengalami penurunan dibandingkan dengan periode Agustus 2019 yang sebesar 1,79 juta orang sedangkan Tingkat Pengangguran Terbuka (TPT) di Provinsi Papua mengalami peningkatan. TPT di Papua pada periode Agustus 2020 sebesar 4,28\% lebih tinggi dibanding periode Agustus 2019 sebesar 3,51\%. Sekitar 229.615 orang atau 9,28\% dari total penduduk usia kerja di Provinsi Papua merasakan dampak pandemi COVID-19 di semua komponen. 
Gambar 2. Jumlah Pengangguran 2018 - 2020 di Provinis Papua

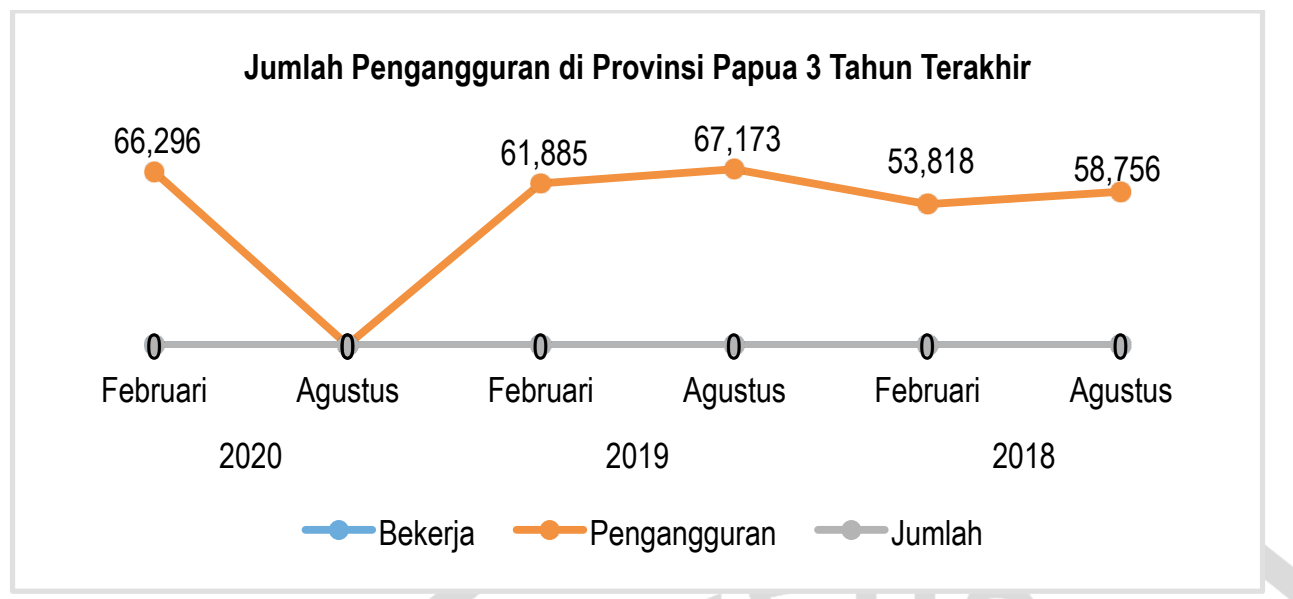

Sumber : Data Provinsi Papua 2020

Kondisi pertumbuhan ekonomi yang terus terkontraksi dapat berdampak pada dunia Kerja di provinsi Papua di mana Tingkat Pengangguran Terbuka (TPT) pada Februari 2020 sebesar 66.296 orang atau meningkat 7,13 persen dibanding Februari 2019 hanya 61.885 orang (meningkat 4.411 orang). Data tenaga kerja di Sektor Informal belum terdata dan bekerja secara of-line, dan sejak 18 Mei 2020, bekerja dari 06,00 s/d 14.00 wit (diberlakukan PSBB). Data membuktikan bahwa sampai bulan Mei 2020, Dampak Covid 19 terhadap pemutusan hubungan kerja di Papua sebanyak 2.602 orang yang dirumahkan, dan data ini tersebar di beberapa kota besar seperti Kota Jayapura sebanyak 1.452 orang, Kabupaten Jayapura sebanyak 465 orang, Keerom sebanyak 79 orang dan Kabupaten Merauke sebanyak 66 orang, (Kadisnaker Provinsi Papua).

Secara umum, perkembangan kondisi kesejahteraan masyarakat Papua yang dilihat dari jumlah dan persentase penduduk miskin pada periode Maret 2020 cenderung meningkat (yoy). Indeks Kedalaman Kemiskinan (P1) mengalami penurunan mencapai 6,16 pada periode Maret 2020 dibandingkan dengan periode Maret 2019 yang mencapai 7,17. Sementara itu, Nilai Tukar Petani Papua (NTP) Papua pada triwulan III 2020 memiliki indeks sebesar 103,59 atau mengalami peningkatan 10,91\% dibandingkan dengan periode yang sama tahun 2019. Nilai tersebut mengindikasikan terjadinya peningkatan kesejahteraan petani di Papua.

\section{Dampak Covid 19 Terhadap Harga 9 Bahan Kebutuhan Pokok di Provinsi Papua}

Dampak lain yang tidak kalah penting untuk dikaji adalah kestabilan harga barang kebutuhan pokok di Provinsi Papua. Harga bahan pokok di Papua selama masa pandemi Covid-19 naik 10 kali lipat dibanding dengan harga yang berlaku di luar pulau Papua. Seperti, harga cabai, bawang merah dan bawang putih, di Surabaya dan Makasar dijual seharga Rp. $22.000 / \mathrm{kg}$, tetapi di Papua dijual Rp.120.000/kg. Berdasarkan hasil Survey yang dilakukan oleh tim Stagas Covid-19 Universitas Cenderawasih menunjukkan bahwa sebanyak 53.10 persen responden (masyarakat) menyatakan bahwa harga 9 bahan kebutuhan pokok masyarakat peningkatan. Walaupun demikian, namun dari hasil survey di kota Jayapura ditemukan 83,30 persen responden masyarakat menyatakan mereka mudah mendapatkan 9 bahan kebutuhan pokok tersebut secara baik. Meskipun demikian, sebanyak 16.3 persen responden yang menyatakan tidak terlayani secara baik, disini juga perlu ditelusuri penyebabnya. Hal ini mungkin diakibatkan karena peluang kerja yang sudah tidak terbuka lagi akibat pandemic Covid 19. 
Gambar 3. Tingkat Inflasi pada 9 bahan kebutuhan pokok Masyarakat di Kota Jayapura

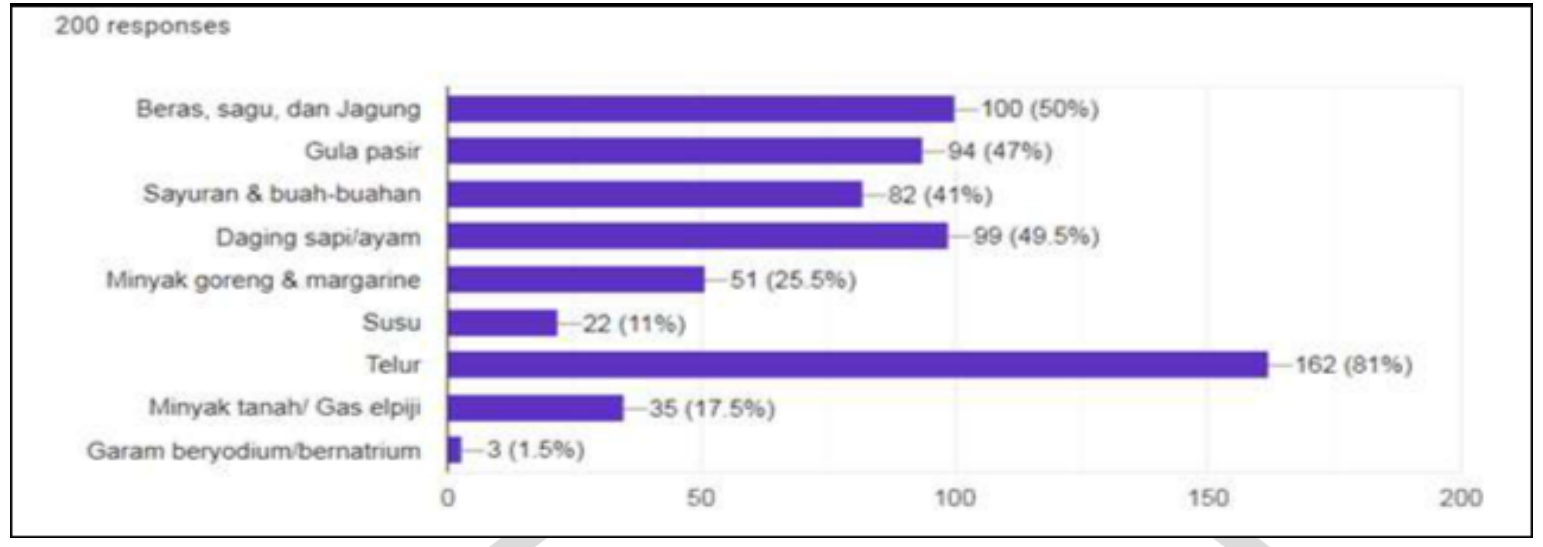

Sumber : Survey Tim Covid'19 Uncen Mei 2020

Gambar 3.2. Survey harga sembilan bahan pokok mengalami kenaikkan, karena terjadi kelangkaan di pasar serta menurunnya daya beli masyarakat sebagai akibat dari menurunnya pendapatan, khususnya bagi keluarga dengan penghasilan harian. Informasi ini perlu menjadi perhatian khusu oleh pemerintah untuk dapat mengupdate harga kebutuhan bahan pokok dimaksud. Khususnya harga (1) telur; (2) beras, jagung, sagu; (3) daging ayam/sapi, (4) gula pasir yang dianggap mengalami lonjakan harga secara signifikan. Oleh karena itu pengawasan stabilitas harga sembako tidak semata menjadi tugas pemerintah daerah, namun melibatkan banyak lembaga yang tergabung dalam Tim Pengendali Inflasi Daerah (TPID). Peran TPID dalam mengendalikan inflasi sangat vital dan sejauh ini berfungsi dengan baik dilihat dari tren inflasi baik tahunan maupun bulanan, terutama selama pandemi. Rilis data BPS Kota Jayapura bahwa pada Juni 2020 terjadi inflasi sebesar 0,15 persen atau terjadi kenaikan angka Indeks Harga Konsumen (IHK) dari 103,92 pada Mei 2020 menjadi 104,01 pada Juni 2020. Sedangkan Laporan BI pada November (2020) menyatakan inflasi di Bumi Cenderawasih pada triwulan III mencapai 1,3 persen lebih terkendali daripada inflasi nasional yang mencapai 1.96 pada periode yanga sama.. Inflasi di Papua saat pandemic covid'19 ini cukup terkendali.

Gambar 4. Perkembangan Inflasih di Provinsi Papua 3 tahun terakhir

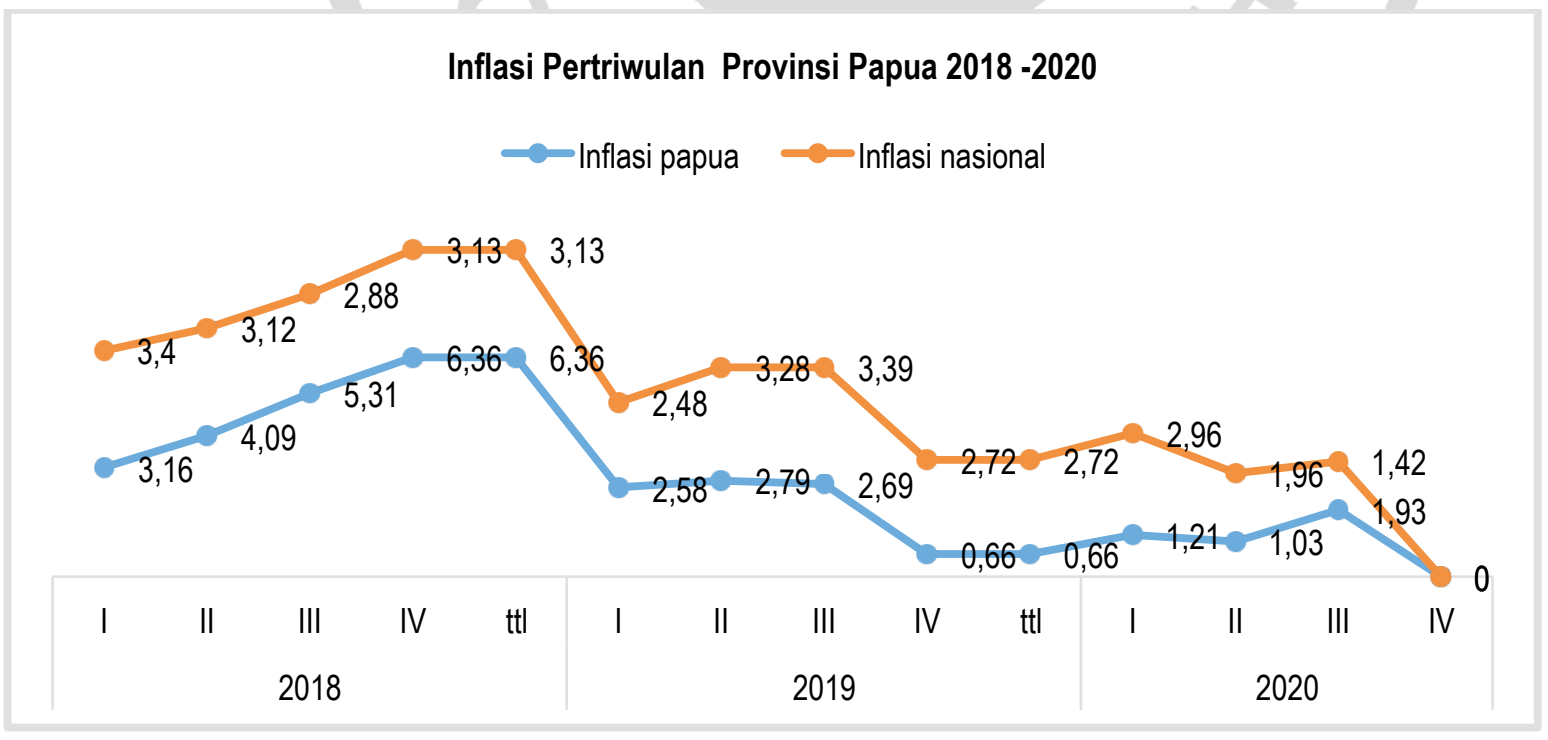

Sumber : Laporan BI November 2020 
Dari sisi Pendapatan dan Belanja sesuai APBD provinsi Papua yang berjumlah Rp. 14 Triliun lebih sampai akhir triwulan I tahun 2020, realisasi serapan anggaran belanja baru mencapai 21,57 persen. Sesuai laporan kementerian Dalam Negeri bahwa penyerapan belanja Provinsi Papua sangat jauh dari rata-rata seratapan nasional sebesar 37,57 persen, dan terendah di seluruh Indonesia. Keterlambatan ini diduga diakibatkan oleh penetapan Perda APBD yang terlambat, menyebabkan terlambatnya pelaksanaan kegiatan; terjadinya gagal lelang, sehingga pemda harus mengulang proses lelang yang pada akhirnya menghambat penyerapan anggaran dan pencapaian output; dan belum selesainya persiapan pelaksanaan kegiatan, misalnya pembebasan tanah adat. Selain itu, factor lain yang diduga kuat berdampak pada rendahnya penyerapan anggaran adalah kapasitas SDM di DPRP mapuan SDM pada OPD teknis yang mengelola belanja daerah. Hal ini perlu menjadi perhatian Kementerian Dalam Negeri. Ada beberapa provinsi yang realisasi serapan anggaran tidak jauh berbeda dengan provinsi Papua antara lain : Sulawesi Tenggara yang sebesar 24,56 persen, Jambi 25,9 persen, Kalimantan Barat 25,9 persen, Maluku Utara 28,98 persen, Sulawesi Barat 29,12 persen, dan Sulawesi Barat 29,12 persen.

Pada saat wabah covid'19 melanda Papua perilaku baru bermunculan, dan salah satunya persepsi masyarakat terhadap ketersediaan kebutuhan pokok bagi masyarakat. Berikut ini hasil survey tim Satgas Civid 19 Universitas Cenderawasih Jayapura.

Dari hasil suvey sebanyak 219 sampel masyarakat di Kota Jayapura sebagai sampel ditemukan jawaban beragam terhadap ketersediaan 9 bahan kebutuhan pokok masyarakat agar tetap terjaga. Hasil survey terkait penilaian masyarakat terhadap ketersediaan ke-9 bahan pokok ini dapat dikategorikan berdasarkan skala Linkert dengan 1=sangat sulit didapat (warna biru), 2=sulit (warna coklat), 3=mudah (warna orange), 4=sangat mudah didapat (warna hijau) diberikan sebagai berikut.

Gambar 5. Respon masyarakat terhadap ketersediaan 9 bahan pokok

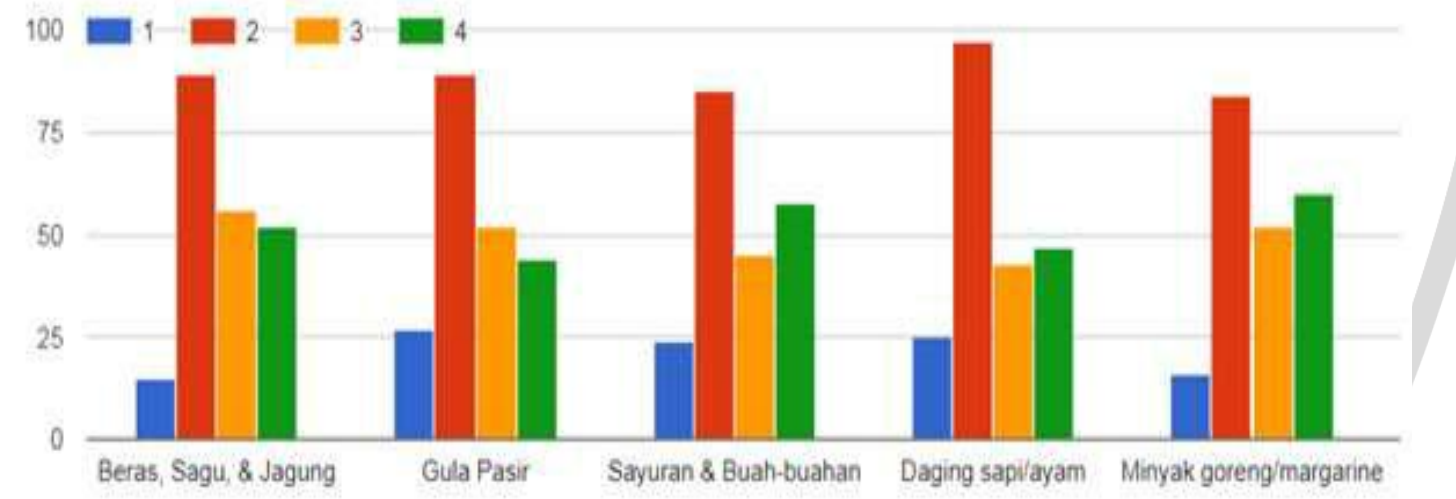

Sumber : Tim Satgas Covid 19 Uncen Mei 2020

Ada perilaku baru yang bermunculan di kalangan masyarakat Papua akibat pandemic Covid'19 dan diberlakukan Work From Home (WFH), banyak masyarakat yang memanfaatkan pekarangan untuk bertanam, seperti hasil survey tim satgas covid Uncen berikut ini. 
Gambar 6. Respon Masyarakat terhadap pemanfaatan Pekarangan di era Covid 19

Apakah lingkungan tempat tinggal saudara memiliki pekarangan untuk ditanami?

211 responses

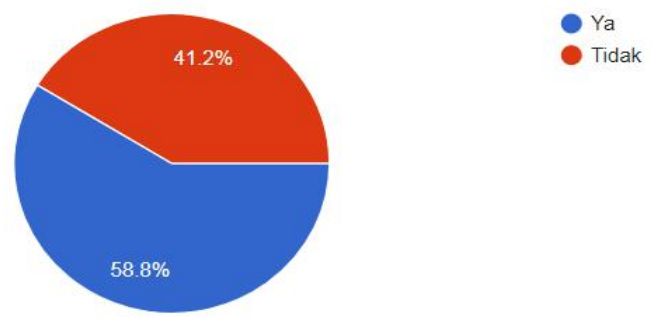

Sumber : Survey Tim Satgas Covid Uncen Mei 2020

Sebanyak $58,8 \%$ responden menyatakan bahwa mereka dapat mengembangkan pekarangan unutk menanam berbagai macam jenis tanaman sebagai suplay dalam mendukung kebutuhan di masa pandei Covid 19 ini. Tanaman yang dikembangkan adalah sayuran, bumbu-bumbu dapur dan tanaman obat-obatan. Ada venomena baru bahwa akibat Covid-19 di seluruh Papua rata-rata OAP \& Non OAP, selain memanfaatkan pekarangan rumah, sebagian besar turun ke ladang mengolah lahan yang selama ini ditinggalkan karena lebih mengkonsumsi nasi dan lainnya.

\section{Dampak Pandemic Covid 19 Terhadap Proses Pembelajaran di Provinsi Papua}

Pandemi Covid'19, selain berdampak pada aktivitas ekonomi masyarakat, aktivitas lain yang terkena dampak adalah kegiatan belajar mengajar dari tingkat TK sampai Perguruan Tinggi. Hasil survey terhadap 219 responden di kota Jayapura menunjukkan bahwa sekitar 52,8\% responden bukan pelajar. Sedangkan 47,2 sebagai siswa, pelajar dan mahasiswa dan yang bertempat tinggal bersama orang tua sebanyak 29 persen, dan 25 persen bertempat tinggal di rumah keluarga serta 36,4 persen menepatkan rumah kost/sewa dan selebihnya dari responden bertempat tinggal asrama dan rumah tinggal lainya.

Gambar 7. Persepsi masyarakat terhadap Pembelajaran melalui media online.

\section{Media pembelajaran berbasis On-Line (sistem Daring I)}

Apakah anda seorang mahasiswa/pelajar?

212 responses

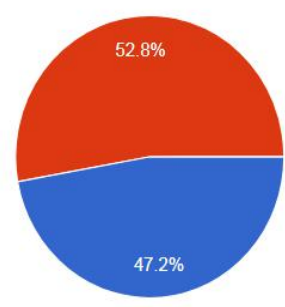

Status tempatitinggal anda saat ini?

176 responses

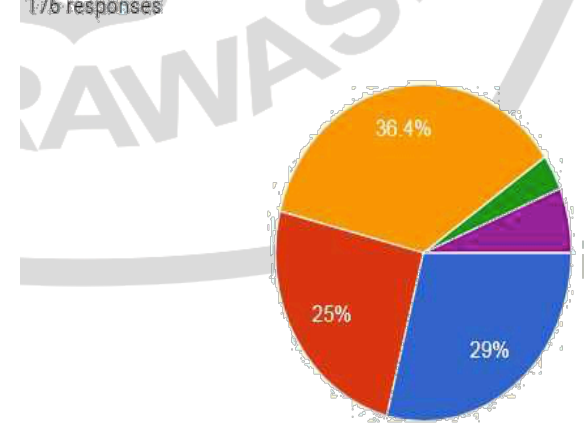

Rumah orang tua

Rumab keluargalfamili

Rumab sewakos

Ostama:

O Lain-nya (misal gubuk)

Mereka yang tinggal di rumah kost dan menumpang dengan keluarga pasti akan menghadpi kendala pada pulsa bahkan handpone. 
Gambar 8. Responden yang Belajar melalui median online

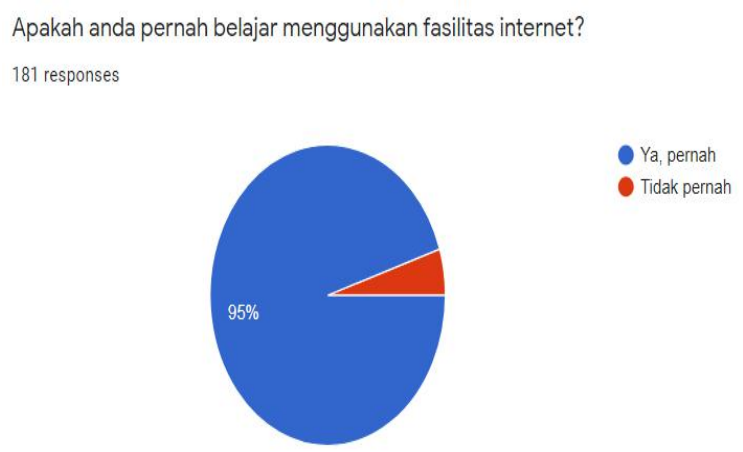

Kendala utama dalam belajar sistem daring atau online?

148 responses

Sumber : Suvey Tim Satgas Covid'19 Uncen Mei 2020

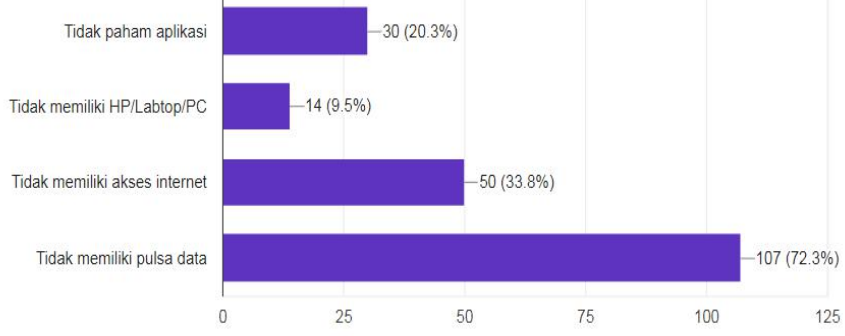

Sebanyak 181 responden atau 95 persen menyatakan bahwa mereka menggunakan fasilitas internet untuk belajar/mengajar di era pandemic Covid 19 ini. Sisanya sebesar 5 persen menyatakan "tidak pernah". Kendala yang dihadapi siswa/mahasiswa adalah tidak memilik pulsa data dan tidak ada akses internet. Medai Pembelajaran yang sering digunakan dalam proses pembelajaran 61,3 persen menggunakan WhatsApp dan 55,4 persen menggunakan aplikasi zoom, sisanya menggunakan lainnya. Responden yang berhasil menjawab kuisioner dari kalangan guru/dosen hanya 23,6 persen.

Gambar 9. Jumlah Responden yang Menggunakan Media Internet dalam Pembelajaran

Media pembelajaran berbasis online atau sistem daring apa yang pernah digunakan?

168 responses

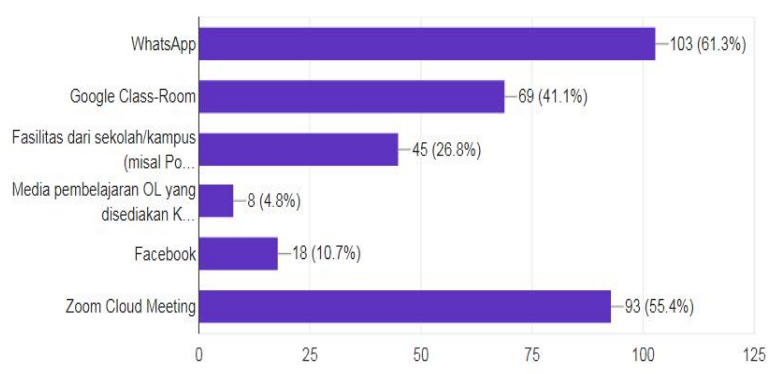

Media pembelajaran berbasis On-Line (sistem Daring)

Apakah anda seorang guru/dosen?

203 responses

Sumber : Hasil Suvey Tim Satgas Covid'19 Uncen Mei 2020

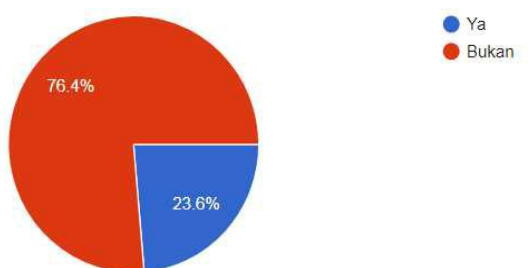

Dari hasil Survey ditemukan juga bahwa sekitar 23,4 persen responden adalah guru/dosen yang tidak pernah menggunakan vasilitas internet sebagai media pembelajaran. Kendala yang dihadapi guru/dosen : tidak tahu atau lainnya dan tidak memiliki akses internet. Bahkan ada responden mahasiswa yang mengacam dosen agar segera menghentikan proses belajar mengajar melalui media online, karena mereka terkendala dengan HP atau Laptop serta pulsa data.

\section{PENUTUP}

\section{A. Simpulan}

Beberapa kesimpulan dari penelitian ini dapat dijelaskan sebagai berikut:

1. Dari kajian ini ditemukan bahwa Dampak Covid 19 terhadap perekonomian Provinsi Papua pada triwulan I tahun 2020, pertumbuhan ekonomi mencapai 1,48 persen (yoy), lebih lambat dibandingkan triwulan sebelumnya ( $q$-toq), Perekonomian terjadi kontraksi sebesar $-6,77$ persen atau turun sebesar $-6,77$ persen. Namun pada triwulan 
II-2020, Ekonomi Papua mengalami pertumbuhan sebesar 4,52 persen (dengan Tambang) (y-on-y). Selanjutnya pertumbuhan ekonomi Papua pada triwukan III tahun 2020 terjadi kontraksi sebesar 2,62 persen, lebih kecil dibandingkan dengan pertumbuhan secara nasional terjadi kontraksi sebesar 3,49 persen.

2. Tingkat Pengangguran Terbuka (TPT) pada Februari 2020 sebesar 66.296 orang atau meningkat 7,13 persen dibanding Februari 2019 hanya 61.885 orang (meningkat 4.411 orang). Dampak Covid 19 terhadap pemutusan hubungan kerja di Papua sebanyak 2.602 orang yang dirumahkan, dan ini tersebar di beberapa kota besar seperti Kota Jayapura sebanyak 1.452 orang, Kabupaten Jayapura sebanyak 465 orang, Keerom sebanyak 79 orang dan Kabupaten Merauke sebanyak 66 orang.

3. Hasil Survey menunjukkan bahwa sebanyak 53.10 persen responden menyatakan bahwa harga 9 bahan kebutuhan pokok mengalami peningkatan masa pandei covi'19. Walaupun demikian, di kota Jayapura ditemukan 83,30 persen responden menyatakan mereka mudah mendapatkan 9 bahan kebutuhan pokok tersebut secara baik.

4. Hasil survey terhadap 219 responden di kota Jayapura menunjukkan bahwa sekitar 52,8 persen responden bukan pelajar dan sisanya sebanyak 47,20 persen (103 orang) adalah pelajar, mahasiswa, guru dan dosen. Dari responden pelajar dan mahasiswa yang disurvey 95 persen (97 orang) responden menyatakan mereka menggunakan fasilitas internet untuk belajar/mengajar di era pandemic Covid 19 ini. Sisanya sebesar 5 persen menyatakan "tidak pernah". Kendala yang dihadapi siswa/mahasiswa adalah tidak memilik pulsa data dan tidak ada akses internet. Aplikasi yang sering digunakan dalam proses pembelajaran 61,3 persen menggunakan WhatsApp dan 55,4 persen menggunakan aplikasi zoom, sisanya menggunakan lainnya. Dari survey ditemukan bahwa 23,4 persen responden adalah guru/dosen yang tidak pernah menggunakan vasilitas internet sebagai media pembelajaran. Kendala yang dihadapi guru/dosen : tidak tahu atau lainnya dan tidak memiliki akses internet.

\section{B. Saran}

Berdasarkan kesimpulan di atas, maka penulis memberikan saran dalam penelitian ini antara lain:

1. Sejak pertengahan Maret 2020 sampai saat ini, masih ditemukan pasien positif Covid-19, dan penularan terjadi secara internal di setiap kota bahkan ditingkat Kelurahan, RW/RT, oleh karena itu, perlu pengawasan yang ketaat oleh pemerintah daerah khusus kabupaten/kota yang berpotensi meningkatkan penyebaran Covid'19.

2. Perlu "koordinasi" yang harmonis antar pemerintah provinsi dengan kabupaten/kota untuk membuat program dan kegiatan yang antar wilayah, karena penyebaran corona virus ini tidak mengenal batas wilayah.

3. Satgas Pengendalian, Pencegahan dan Penanganan Covid-19 di tingkat kabupaten/kota wajib mensosilisasikan kedisiplinan masyarakat secara terus menerus, karena tingkat kedisiplinan masyarakat masih sangat rendah, terutama menanamkan kesadaran kepada masyarakat untuk menerapkan $3 \mathrm{M}$ (mencuci tangan, memakai masker dan menjaga jarak)

4. Perlu pendataan yang baik tentang masyarakat yang layak menerima bantuan bama, sehingga akan terhindar dari pendobolan penerima, karena saat ini ada sebagian masyarakat belum terlayani secara baik. Dan juga perlu pembentukan satgas ekonomi masyarakat yang mengontrol penyaluran bama serta mengontrol harga-harga sembilan bahan pokok sampai pada proses supply dan distribusinya.

5. Perlu ada kebijakan stimulus Riil dan nyata yang perlu dilakukan oleh pemerintah provinsi maupun kabupaten/kota yang dapat menyentuh Masyarakat terutama UKMK terkena dampak dan juga para pekerja disektor jasa yang saat ini kehilangan mata pencaharian, hal ini diharapkan akan meningkatkan daya beli masayakat memulai usaha dan kerja di era kerja baru ini.

6. Lembaga pendidikan terutama perguruan tinggi perlu menyiapkan salah satu media belajar online yang mudah untuk digunakan oleh guru/dosen dalam proses pembelajaran, selanjutnya lembaga pendidikan maupun pemerintah perlu mempersiapkan jaringan internet gratis yang memadai pada area-area tertentu yang mudah diakses oleh pelajar dan mahasiswa.

7. Perlu ada kebijakan khusus bagi pelajar/mahasiswa yang terkendala dengan belajar melalui media online. 


\section{DAFTAR PUSTAKA}

Agus Purwanto*, Rudy Pramono, Masduki Asbari, Priyono Budi Santoso, Laksmi Mayesti Wijayanti, Choi Chi Hyun, Ratna Setyowati Putri (2020). Studi Eksploratif Dampak Pandemi COVID-19 Terhadap Proses Pembelajaran Online di Sekolah Dasar. Jurnal EduPsyCoun Jurnal (Jurnal of Education, Psychology and Counceling)

BPS Provinsi Papua, Perkembangan Indeks Harga Konsumen/Inflasi Gabungan 3 Kota di Papua Februari 2020 No. 15/03/94/Th.XXII, 2 Maret 2020

BPS Provinsi Papua, Pertumbuhan Ekonomi Papua Triwulan II-2020 No. 44/08/94/Th.XIII, 05 Agustus 2020

BI, LAPORAN PEREKONOMIAN PROVINSI PAPUA NOVEMBER 2020

https://www.bi.go.id/id/publikasi/laporan/Pages/Laporan-Perekonomian-Provinsi-Papua-November-2020.aspx

Dito Aditia Darma Nasution1), Erlina2) dan Iskandar Muda3), 2020. Dampak Pandemi Covid 19 Terhadap Perekonomian Indonesia, diterbitkan pada Jurnal Benefita 5(2) Juli 2020 (212-224) LLDIKTI Wilayah X 212

Kementerian Kesehatan RI (GERMAS) 2020. Pedoman Pemberdayaan Masyarakat Dalam Pencegahan Covid 19,di tingkat $\mathrm{RT} / \mathrm{RW}$ dan Desa

Laporan Perekonomian Provinsi Papuan November 2020, Vol. 6 No. 3 TRIWULANAN : Juli - September 2020 (terbit November 2020) triwulan III 2020

Laporan Suvey Satgas Covid 19 Universitas Cenderawasih Jayapura, Mei 2020

Laporan Dampak Covid -19 Pada Perekonomian Daerah Provinsi Sulawesi Selatan (SULSEL), Oleh Pengurus Cabang ISEI Makassar 2020

https://humas.polri.go.id/2020/04/25/kapolda-papua-hadiri-rapat-koordinasi-dampak-covid-19-terhadap-perekonomian-diprovinsi-papual

Jurnal Benefita 5(2) Juli 2020 (212-224)

https://www.researchgate.net/publication/343354798_Dampak_Pandemi_COVID-19_terhadap_Perekonomian_Indonesia

https://ummaspul.e-journal.id/Edupsycouns/article/view/423

Hanoatubun, S. (2020). Dampak Covid - 19 terhadap Prekonomian Indonesia. EduPsyCouns: Journal of Education,

Psychology and Counseling, 2(1), 146-153. Retrieved from https://ummaspul.e-

journal.id/Edupsycouns/article/view/423

Sutaryo, Prof. Dr. dr., Sp.A (Ak), Natas Yang, dr., Lintang Sogor, dr., dan Dea Sella Sabrina, dr., (2020) Buku Praktis Penyakit Virus Corona 19 (Covid 10), UGM Press.

https://www.google.com/search?q=pertumbuhan+ekonomi+papua+2020\&oq=\&aqs=chrome.0.69i59i45018.985479862j0j15\& sourceid=chrome\&ie $=$ UTF-8

file://IE:/FILE\%20DEKAN/Draft\%20Jurnal\%20Kovid-19\%20-

\%20\%202020/Laporan\%20Perekonomian\%20Provinsi\%20Papua\%20November\%202020.pdf

https://www.merdeka.com/trending/kronologi-munculnya-covid-19-di-indonesia-hingga-terbit-keppres-darurat-kesehatankln.html?page=4 